\title{
Morphological and Cultural Variability in Rice Isolates of Rhizoctonia solani Kuhn causing Sheath Blight Disease of Rice
}

\author{
Rajat Kumar ${ }^{1}$, Abhilasha A. Lal ${ }^{1}$, Sobita Simon ${ }^{2}$ and B. Ravi Teja Naidu ${ }^{2 *}$ \\ ${ }^{1}$ Department of Plant Pathology, Sam Higginbottom University of Agriculture, Technology \\ and Sciences, Prayagraj- (UP), India [RK, AAL, SS] \\ ${ }^{2}$ Department of Plant Pathology, Ranchi Agriculture College, Birsa Agricultural University, \\ Ranchi, (Jharkhand), India [BRTN] \\ *Corresponding author
}

A B S T R A C T

\begin{tabular}{|c|}
\hline Keywords \\
\hline $\begin{array}{l}\text { Rice, Sheath blight, } \\
\text { Rhizoctonia solani, } \\
\text { survey, Cultural and } \\
\text { Morphological } \\
\text { characterizations }\end{array}$ \\
\hline Article Info \\
\hline $\begin{array}{l}\text { Accepted: } \\
10 \text { November } 2020 \\
\text { Available Online: } \\
10 \text { December } 2020\end{array}$ \\
\hline
\end{tabular}

The fungal disease sheath blight of rice caused by Rhizoctonia solani is an economically important disease of rice in India. A survey was carried out to find the disease severity of sheath blight of rice and collected the specimens from the different locations of Prayagraj district. Thirteen isolates of $R$. solani collected from different locations of Prayagraj district were studied for their morphological and cultural characterization. All isolates showed wide morphological and cultural variations in terms of colours (white, whitish yellow, light cream and pale-yellow) colony behavior (upper touch lid and no-upper touch lid), radial growth (slow, moderate and fast growing), sclerotia colour (brown, light brown, dark brown, and deep dark brown), sclerotia distribution pattern (scattered, peripheral and scattered-peripheral) and sclerotia weight (ranged between $0.123-0.233 \mathrm{~g}$ ).

\section{Introduction}

Rice suffers from many diseases caused by fungi, bacteria, viruses, phytoplasma, nematodes and other non-parasitic disorders. Sheath blight is the fungal disease of rice caused by Rhizoctonia solani Kuhn considered to be one the most destructive fungal disease. Sheath blight disease of rice is an economically important in many rice growing regions. Its causes up to $50 \%$ yield loss under favorable condition around the world (Groth, 2008 and Bernardes, 2009). In Eastern Asia, it is reported that sheath blight disease of rice causes yearly yield loss up to 6 million tons of rice grain by affecting nearly 15-20 million ha of rice under irrigated condition (Bernardes, 2009).

The pathogen Rhizoctonia solani is most widely distributed causing diseases in many crops. Rhizoctonia solani causes stem rot, fruit rot, fruit and seed decay, foliar blight, damping off, crown rot and stem canker in 
various crops (Baker, 1970; Anderson, 1982). Many attempts have been made to organize R. solani isolates into groups on the basis of various morphological, cultural and pathological characteristics (Sherwood, 1969).

The earlier studies suggest that sheath blight pathogen $R$. solani was found homogenous in nature (Kuninaga et al., 1982) but recent investigations revealed that the pathogen is more diverse than previously assumed (Neeraja et al., 2002, Singh et al., 2002, Susheela et al., 2004, Yu et al., 2003) Keeping in view, the present investigation was carried out to determine the morphological and cultural variability in 13 isolates of $R$. solani from rice crop.

\section{Materials and Methods}

\section{Survey and collection of Rhizoctonia solani isolates from different regions of Prayagraj district}

\section{Collection of samples}

A survey was carried out to collect different samples of rice for isolation of different Rhizoctonia solani isolates from selected areas of Prayagraj district (Table 1). The details of collected isolates given in Table 1 . The in which the different isolates were collected and denoted as PRS_1 to PRS_20. Due to unfavourable conditions some isolates (viz., PRS_4, PRS-5, PRS_6, PRS_11, PRS_15, PRS_17 and PRS_20) were contaminated and unable togrow as such they were not used for further study.

\section{Isolation of pathogen}

The diseased plant parts were washed in running water followed by sterile distilled water to remove surface contaminants. Then the tissues were dissected in to $0.5-1 \mathrm{~cm}$ size with a sterile blade. The cut pieces were surface sterilized with $2 \%$ sodium hypochlorite solution for $1 \mathrm{~min}$ and rinsed three times with sterile distilled water. After surface drying, disease tissues were placed on water agar and incubated at $28{ }^{\circ} \mathrm{C}$ for $24 \mathrm{~h}$.

Later, pure cultures for all isolates were prepared by transferring mycelial tips to potato dextrose agar (PDA) medium. After 2 to 3 days, cultures were examined microscopically for hyphal characteristics typical to $R$. solani.

\section{Morphological study}

To study about morphological character of isolates, a $5 \mathrm{~mm}$ disc from 5 days old active colony of each isolate was inoculated in the center of Petri plate $(90 \mathrm{~mm}$ diameter) containing Potato Dextrose Agar (PDA). All isolates were replicated thrice.

The observations on colony colour, radial growth and behaviour were recorded at 7 day after incubation (DAI) and sclerotia distribution pattern, its colour, and weight ( $\mathrm{g}$ ) of each isolate were recorded after 15 DAI.

\section{Disease assessment}

The disease severity were recorded by following Standard Evaluation System (SES) for rice (IRRI, 1996) and the per cent disease reduction over the control will be calculate. The lesion height and plant height were measured. Relative Lesion Height (RLH) was calculate using the following formula.

$$
\text { RLH= } \frac{\text { Lesionheight }}{\text { Plantheight }} \times 100
$$

For evaluating the efficacy of the antagonistic fungi against sheath blight disease, the following 0-9 scale given by IRRI (1996)was used (Table 2 and Figure 1). 


\section{Results and Discussion}

Sheath blight disease of rice was identified in the farmer's fields based on key symptoms of circular, oblong or ellipsoid, greenish-grey water soaked spots about $1 \mathrm{~cm}$ long that occur on leaf sheath near water level. Based on these key symptoms, sheath blight rice Per cent Disease Incidence (PDI) was assessed in farmers' fields of each village nineteen villages and 8 blocks in Prayagraj district.

A survey was carried out for recording the diseases everity and to collect different samples of rice for isolation of different Rhizoctonia solani isolates from different areas of Prayagraj district.

Sheath blight of rice was prevalent in all the areas surveyed and the diseases everity varied from 5.10 to $13.5 \%$ depending upon the regions. However, highest disease severity was recorded in Leudi village under Jasra block i.e.13.4\% followed by village Naini under Chaka block which recorded disease severity of 10.6. The data presented in Table 3 reveals that relative lower disease severity were recorded in Chaka village under Chaka block leaf disease intensity $5.76 \%$.

The variations in the diseases severity among the surveyed regions may be due to different environmental conditions, different practices farmers adopted or can be different varietal or genotypes of rice crop or mean disease incidence which might be attributed to balanced fertilization especially of nitrogenous fertilizers by the farmers of the village. Kapse et al., (2012) surveyed rice growing area in Jabalpur region and recorded the diseases incidence of sheath blight of rice between 2-24\%. Thakur et al., (2017) surveyed different rice growing regions of Chhattisgarh to record and analyze disease incidence of sheath blight of rice and maximum disease incidence observed in November 2014 i.e. 82.2\%. Pal et al., (2015) surveyed west central table land zone (viz., Sambalpur, Bargarh and Jharsuguda) of Odisha region to record and analyse the incidence of sheath blight of rice. Among the districts surveyed, the highest mean disease incidence recorded in Bargarh district i.e. $30.19 \%$ and the least mean disease incidence recorded in Jharsuguda district i.e. $21.98 \%$. A positive relation was also observed between dose of nitrogenous fertilizers used by the farmers and disease incidence percentage.

\section{Cultural and morphological variability of different Rhizoctonia solani isolates}

Cultural and morphological variability includes colony behaviour, radial growth, colony colour, sclerotia colour, sclerotia distribution pattern, and sclerotia weight $(\mathrm{g})$. All the isolates were grown on Petri plates. Then, all the isolates were observed under microscope for identification. The results of this study revealed that growth of $R$. solani was observed in different colours like, white, whitish yellow, light cream and pale yellow. Growth of the pathogen varied from slow growth, moderate growth and fast growth as in some isolates it touched the upper lid of the Petri plates. For ease to study the different $R$. solani isolates characterized as PRS_1, PRS_2 PRS_3 and so on.

\section{Identification and morphological studies of pathogen}

The fungus found to be responsible for sheath blight disease of rice and grown Potato Dextrose Agar (PDA) medium. Morphological characters were studied under compound microscope.

The pathogen was isolated in Potato Dextrose Agar (PDA) media and purified. The 
pathogen produced white mycelial growth at first but later on it turned into light cream colour to yellowish cream colour. The mycelium was septate and hyaline. Further the mycelia aggregated and formed the sclerotia with respected colour and pattern of distribution.

\section{Cultural variability among $\boldsymbol{R}$. solaniIsolates on Potato Dextrose Agar Medium}

\section{Colony colour}

Colony colour change was recorded on fourteen days after incubation. In the present study, colony colour among the 13 isolates varied as white, whitish yellow, light cream and pale-yellow (Table 1 and Fig. 2). Out of 13 isolates, 2 isolates were white (PRS_2 and PRS_9), 5 isolates were whitish yellow (PRS_1, PRS_3, PRS_8, PRS_13 and PRS_18), 4 isolates were light cream (PRS_7,
PRS_10, PRS_14 and PRS_16) and 2 isolates were pale yellow (PRS_12 and PRS_19). The colour creation may likewise be because of arrival of other secondary metabolites like toxins (Zhang et al., 1995) examined the cultural and morphological variability of $R$. solani isolates confines and found that the $R$. solani isolates varied pale brown coloured to brownish colony on agar medium.

\section{Colony behaviour}

Variations in colony behaviour was recorded among the thirteen isolates. In the present study, colony behaviouramong the 13 isolates varied as upper touch lid and no-upper touch lid (Table 4 and Fig. 2). Out of 13 isolates 3 were upper touch lid (PRS_8, PRS_13 and PRS_14) and 10 were no-upper touch lid (PRS_1, PRS_2, PRS_3, PRS_7, PRS_9, PRS_10, PRS_12, PRS_16, PRS_18 and PRS_19).

Table.1 Isolates collected from different regions of Prayagraj district

\begin{tabular}{|c|c|c|c|}
\hline Isolate codes & Village & Rice varieties & Samples of \\
\hline PRS_1 & SHUATS CRF & $\begin{array}{c}\text { SHIATS } \\
\text { Dhan-3 }\end{array}$ & Sheath \\
\hline PRS_2 & PurwaKhas & Ganga Kaveri & Sheath \\
\hline PRS_3 & Indalpur & Balwan & Sheath \\
\hline PRS_7 & Naini & 1509 & Sheath \\
\hline PRS_8 & Karchana & Basmati & Sheath \\
\hline PRS_9 & Ghatwa & Basmati & Sheath \\
\hline PRS_10 & Jhusi & Pant Gold & Leaf \\
\hline PRS_12 & Kandhi & Balwan & Sheath \\
\hline PRS_13 & Bhaiya & Ganga-Kaveri & Sheath \\
\hline PRS_14 & Mamoli & 1509 & Sheath \\
\hline PRS_16 & SHUATS CRF & PB-1 & Leaf \\
\hline PRS_18 & (Trial) & & Leaf \\
\hline PRS_19 & Leudi & 1121 & Sheath \\
\hline
\end{tabular}


Table. 2 The Scale for Disease assessment of rice sheath blight caused by $R$. solani

\begin{tabular}{|l|l|}
\hline Score & Disease Description \\
\hline 0 & No infection \\
\hline 1 & Lesion limited to lower 20 per cent of height of the plant \\
\hline 3 & Lesion limited to lower 21-30 per cent of the height of the plant. \\
\hline 5 & Lesion limited to lower 31-45 per cent of the height of the plant. \\
\hline $\mathbf{7}$ & Lesion limited to lower 46-65 per cent of the height of the plant. \\
\hline $\mathbf{9}$ & Lesion more than 65 per cent of the height of the plant. \\
\hline
\end{tabular}

Table.3 Survey for natural occurrence on sheath blight disease incidence of rice in different regions of Prayagraj district

\begin{tabular}{|c|c|c|c|c|c|}
\hline Block & Village & Variety & Crop Stage & $\begin{array}{c}\text { Disease } \\
\text { Severity }(\%)\end{array}$ & $\begin{array}{l}\text { Range DS } \\
(\%)\end{array}$ \\
\hline \multirow{8}{*}{ Chaka } & $\begin{array}{c}\text { SHUATS } \\
\text { CRF }\end{array}$ & SHIATS Dhan-3 & Max. Tillering & 5.93 & \multirow[t]{8}{*}{$5.04-10.60$} \\
\hline & Chaka & Sugandh & Booting & 5.04 & \\
\hline & PurwaKhas & Ganga Kaveri & Booting & 6.47 & \\
\hline & Baswar & Basmati & Max. Tillering & 6.73 & \\
\hline & Mahewa & Basmati & Booting & 9.53 & \\
\hline & Indalpur & Balwan & Booting & 6.4 & \\
\hline & Naini & 1509 & Tillering & 10.6 & \\
\hline & Dandi & 1121 & Max. Tillering & 6.8 & \\
\hline \multirow{4}{*}{ Karchana } & Karchana & NarendraDhan & Max. Tillering & 8.8 & \multirow[t]{4}{*}{ 6.33-8.87 } \\
\hline & Ghatwa & Basmati & Booting & 8.87 & \\
\hline & Jhusi & Pant Gold & Booting & 6.33 & \\
\hline & Kandhi & Balwan & Booting & 8.13 & \\
\hline \multirow[b]{2}{*}{ Jasra } & Leudi & 1121 & Flowering & 13.4 & \multirow[t]{2}{*}{ 8.67-13.40 } \\
\hline & Rigwan & IR66 & Flowering & 8.67 & \\
\hline \multirow[b]{2}{*}{ Meja } & Bhaiya & Ganga-Kaveri & Booting & 8.87 & \multirow[t]{2}{*}{ 8.13-8.87 } \\
\hline & Mamoli & 1509 & Booting & 8.13 & \\
\hline \multirow{3}{*}{ Soraon } & Soraon & Pant Gold & Max. Tillering & 9.27 & \multirow[t]{3}{*}{ 6.48-9.27 } \\
\hline & Jallupur & Basmati & Max. Tillering & 6.48 & \\
\hline & Dasapur & 1509 & Booting & 8.33 & \\
\hline
\end{tabular}


Table.4 Cultural and morphological characters of different isolates of Rhizoctonia solani

\begin{tabular}{|c|c|c|c|c|c|c|}
\hline Isolate & $\begin{array}{l}\text { Colony } \\
\text { Colour }\end{array}$ & $\begin{array}{l}\text { Colony } \\
\text { Behaviour }\end{array}$ & Radial Growth & $\begin{array}{l}\text { Sclerotia } \\
\text { Colour }\end{array}$ & $\begin{array}{l}\text { Sclerotia } \\
\text { Distribution } \\
\text { Pattern }\end{array}$ & $\begin{array}{c}\text { Sclerotia } \\
\text { Weight } \\
\text { (g) }\end{array}$ \\
\hline PRS_1 & $\begin{array}{l}\text { Whitish } \\
\text { yellow }\end{array}$ & No upper lid touch & $\begin{array}{l}\text { Moderate } \\
\text { growing }\end{array}$ & Brown & $\begin{array}{l}\text { Scattered- } \\
\text { peripheral }\end{array}$ & 0.187 \\
\hline PRS_2 & White & No upper lid touch & $\begin{array}{l}\text { Moderate } \\
\text { growing }\end{array}$ & Light brown & Peripheral & 0.147 \\
\hline PRS_3 & $\begin{array}{l}\text { Whitish } \\
\text { yellow }\end{array}$ & No upper lid touch & $\begin{array}{l}\text { Moderate } \\
\text { growing }\end{array}$ & Brown & Peripheral & 0.157 \\
\hline PRS_7 & Light cream & No upper lid touch & Fast growing & Deep dark brown & $\begin{array}{l}\text { Scattered- } \\
\text { peripheral }\end{array}$ & 0.123 \\
\hline PRS_8 & $\begin{array}{l}\text { Whitish } \\
\text { yellow }\end{array}$ & Upper lid touch & Fast growing & Brown & Scattered & 0.213 \\
\hline PRS_9 & White & No upper lid touch & $\begin{array}{l}\text { Moderate } \\
\text { growing }\end{array}$ & Brown & Peripheral & 0.183 \\
\hline PRS_10 & Light cream & No upper lid touch & Slow growing & Brown & Peripheral & 0.206 \\
\hline PRS_12 & Pale yellow & No upper lid touch & $\begin{array}{l}\text { Moderate } \\
\text { growing }\end{array}$ & Brown & Peripheral & 0.163 \\
\hline PRS_13 & $\begin{array}{l}\text { Whitish } \\
\text { yellow }\end{array}$ & Upper lid touch & Fast growing & Light brown & Scattered & 0.207 \\
\hline PRS_14 & Light cream & Upper lid touch & Slow growing & Brown & Peripheral & 0.217 \\
\hline PRS_16 & Light cream & No upper lid touch & $\begin{array}{l}\text { Moderate } \\
\text { growing }\end{array}$ & Light brown & Peripheral & 0.233 \\
\hline PRS_18 & $\begin{array}{l}\text { Whitish } \\
\text { yellow }\end{array}$ & No upper lid touch & Slow growing & Brown & Peripheral & 0.167 \\
\hline PRS_19 & Pale yellow & No upper lid touch & $\begin{array}{l}\text { Moderate } \\
\text { growing }\end{array}$ & Dark brown & Scattered & 0.187 \\
\hline
\end{tabular}

Fig.1 Rice sheath blight grade chart

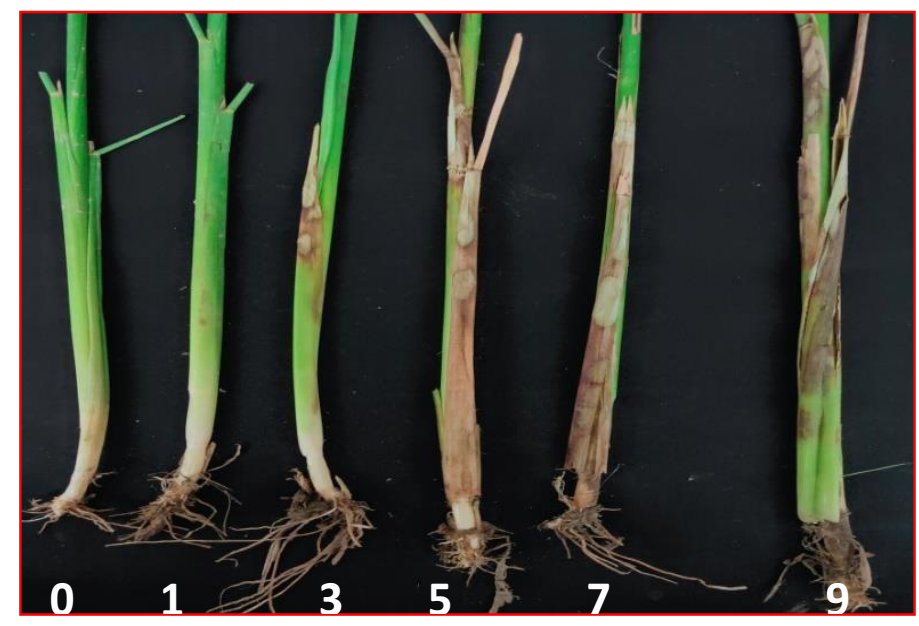


Fig.2 Mycelial growth of Rhizoctonia solani isolates along with sclerotia

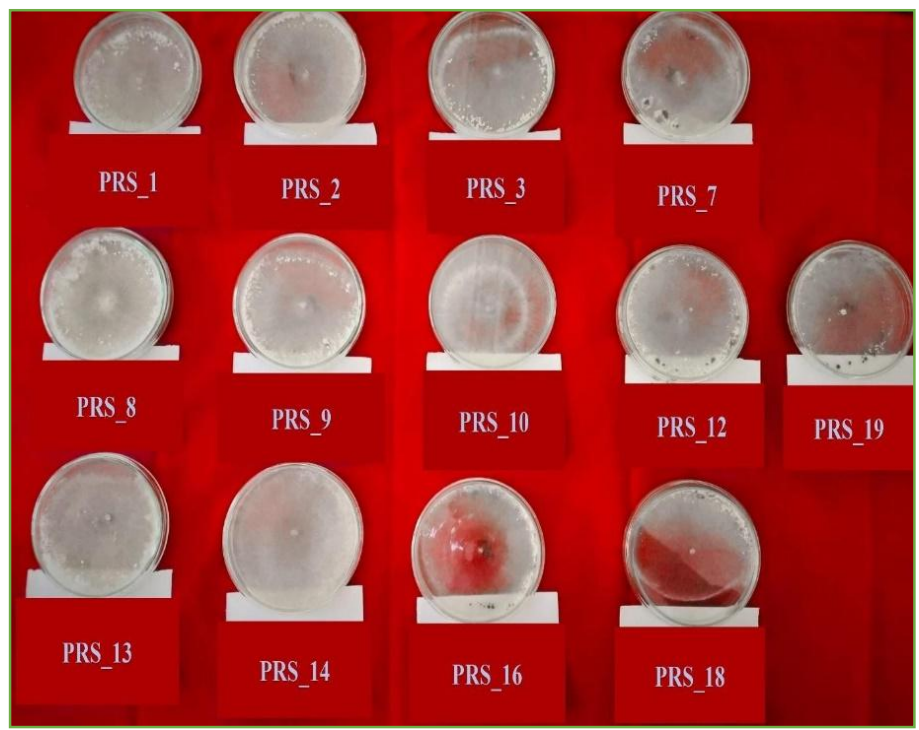

\section{Radial growth}

Variations in radial growth was recorded among the thirteen isolates. In the present study, colony behavior among the 13 isolates varied as slow, moderate and fast growing (Table 4 and Fig. 2). Out of 13 isolates 3 isolates were slow growing (PRS_10, PRS_14 and PRS_18), 7 isolates were moderate growing (PRS_1, PRS_2, PRS_3, PRS_9, PRS_12, PRS_16 and PRS_19) and 3 isolates were fast growing (PRS_7, PRS_8, and PRS_13).Thind and Aggarwal (2008) stated that the growth Rhizoctonia solani isolates from potato and rice categorized as slow, medium and fast growing. Guleriaet al., (2007) reported that the Rhizoctonia solani isolates from rice crop were fast growth per day indicating their fast growing nature.

\section{Sclerotia colour}

Variations in sclerotia colour was recorded among the thirteen isolates. In the present study, sclerotia colour among the 13 isolates varied as brown, light brown, dark brown, and deep dark brown (Table 4 and Fig. 2). Out of 13 isolates 8 isolates were brown (PRS_1,
PRS_3, PRS_8, PRS_9, PRS_10, PRS_12, PRS_14 and PRS_18), 3 isolates were light brown (PRS_2, PRS_13 and PRS_16), 1 isolate was dark brown (PRS_19) and 1 isolate was deep dark brown (PRS_7). Susheela and Reddy (2013) characterized the sclerotia colour 35 isolates of Rhizoctonia solani as brown, dark brown and deep dark brown.

\section{Sclerotia distribution pattern}

Variations in sclerotia distribution patternwas recorded among the thirteen isolates. In the present study, sclerotia distribution pattern among the 13 isolates varied as scattered, peripheral and scattered-peripheral (Table 4 and Fig. 2). Out of 13 isolates 3 were scattered (PRS_8, PRS_13 and PRS_19), 8 were peripheral (PRS_2, PRS_3, PRS_9, PRS_10, PRS_12, PRS_14, PRS_16 and PRS_18) and 2 were scattered-peripheral (PRS_1 and PRS_7). Ganeshamoorti and Dubey (2015) stated that sclerotia distribution of the Rhizoctonia solani isolates showed scattered, peripheral, center ring, peripheral ring pattern of sclerotia distribution. These results were also in agreement with findings 
of Thind and Aggarwal (2008), Lal and Kandhari (2009) and Yaduman et al., (2019)

\section{Sclerotia weight}

Sclerotia weight was recorded among the thirteen isolates in grams (Table 4 and Fig. 2). In the present study, there was variation in the sclerotia weight among the 13 isolates. Srinivas et al., (2007) and Yadumanet al., (2019) found the sclerotia weight variations among the isolates.

In conclusion the findings of the present study confirmed the variability in $R$. solani isolates from rice crop, according to their morphological and cultural characters, which include different colony and sclerotial characters. Based on results in the present study on variability in $R$. solani, it can be concluded that present results will be useful for resistant breeding and effective management of the diseases in rice.

\section{References}

Anderson, N.A., 1982. The genetics and pathology of Rhizoctonia solani. Annu Rev Phytopathology, 20:329-347.

Baker, K.F., 1970. Types of Rhizoctonia diseases and their occurrence. In: Parameter JR Jr (ed.), Rhizoctonia solani Biology and Pathology, Berkeley, USA, University of California Press, pp. 124-148.

Bernardes, J., 2009. Genetic structure of populations of the rice infecting pathogen Rhizoctonia solani AG-1 IA from China, Phytopathology, 99, 10901099.

Ganeshamoorthi, P. and Dubey, S. C., 2013. Anastomosis grouping and genetic diversity analysis of Rhizoctonia solani isolates causing wet root rot in chickpea. African Journal of Biotechnology, 12: 6159-6169.
Groth D.E.,2008. Effects of cultivar resistance and single fungicide application on rice sheath blight, yield and quality, Crop Protection, 27, 1125-1130.

Guleria, S., Aggarwal, R., Thind, T. S. and Sharma, T. R., 2007. Morphological and pathological variability in rice isolates of Rhizoctonia solani and molecular analysis of their genetic variability. Journal of Phytopathology 155: 654661.

IRRI 1996. IRRI towards 2000 and beyond. International Rice Research Institute, P.O. Box 993, Manila, Philippines.

Kuninaga S. and Yokosawa R., 1982. DNA base sequence homology in Rhizoctonia solani Kühn. I. Genetic relatedness within anastomosis group 1, Ann. Phytopathol. Soc. Jpn., 48, 659-667.

Lal, M., Singh, V., Kandhari, J., Sharma, P. and Kumar, V., 2014. Diversity analysis of Rhizoctonia solani causing sheath blight of rice in India. African Journal of Biotechnology. 13(51): 4594-4605.

Mayer A.M., Harel E. and Shaul R.B., 1965. Assay of catechol oxidase -a critical comparison of methods, Phytochemistry, 5, 783- 789.

Sherwood, R.T., 1969. Morphology and physiology in four anastomosis groups of Thanatephorus cucumeris. Phytopathology 59:1924-1929.

Singh, V., Singh U.S., Singh, K.P., Singh, M. and Kumar, A., 2002. Genetic diversity of Rhizoctonia solani isolates from rice: Differentiation by morphological characteristics, pathogenecity, anastomosis behaviour and RAPD fingerprinting, Journal of Mycology and Plant Pathology., 32, 332-344.

Srinivas P., Aggarwal, R. and Sharma, R.C., 2007. Variability in sclerotial morphology of Rhizoctonia solani f. sp. sasakii incitant of banded leaf and sheath blight of maize as revealed through Scanning Electron 
Microscope.Indian Phytopathology. 60 (1): 58-62

Susheela K., Reddy C.S., Biradar S.K., Sundaram R.M., Balachandran S.M. and Neeraja C.N. 2004. Variation among the isolates of Rhizoctonia solani, causing sheath blight disease in rice, In $9^{\text {th }}$ National Rice Biotechnology Network Meeting, IARI, New Delhi, from April 15-17, 119-121.

Susheela, K. and Reddy, C. S., 2013. Variability in Rhizoctonia solani (AG-1 IA) isolates causing sheath blight of rice in India. Indian Phytopathology. 66 (4): 341-350.

Thind, T.S, Aggarwal, R., 2008. Characterization and pathogenic relationships of Rhizoctonia solani isolates in a potato-rice system and their sensitivity to fungicides. Journal of Phytopathology, 156 (10): 615-621.

Yaduman, R., Singh, S. and Lal, A. A., 2019.Morphological and pathological variability of different isolates of Rhizoctonia solani Kuhn causing sheath blight disease of rice. Plant Cell Biotechnology and Molecular Biology. 20 (1\&2):73-80.

Yu J.F., Zhang X.G., Li H.M. and Zhang T.Y.,2003. Genetic variation of isolates of Rhizoctonia solani AG-1 in Yunnan Province, Mycosystema, 22, 69-73.

\section{How to cite this article:}

Rajat Kumar, Abhilasha A. Lal, Sobita Simon and Ravi Teja Naidu, B. 2020. Morphological and Cultural Variability in Rice Isolates of Rhizoctonia solani Kuhn causing Sheath Blight Disease of Rice. Int.J.Curr.Microbiol.App.Sci. 9(12): 868-876.

doi: https://doi.org/10.20546/ijcmas.2020.912.104 